\title{
The Nationalization of Liturgy in the Orthodox Church of Finland in the 1920s-30s
}

\author{
Maria TAKala-Roszczenko*
}

\begin{abstract}
The article explores the nationalization of the Orthodox liturgical tradition in Finland in the 1920s-30s. It was a process through which the Finnish Orthodox tried to remove signs of Russian heritage from their church culture in order to prove their loyalty to the newly independent Republic of Finland. The analysis of the national discourse reveals how the contemporary writers justified the nationalizing reforms.
\end{abstract}

Keywords: nationalization, Finnicization, Orthodox Church of Finland, liturgical reform, liturgical adaptation

\section{Introduction}

On 26 November 1918, the Orthodox (contemporarily called Greek Catholic) Church was declared a state Church in the newly established independent Republic of Finland, next to the Evangelical Lutheran Church, which constituted the majority denomination. ${ }^{1}$ Through this, the Orthodox Church of Finland was severed from the Russian Orthodox Church and, in 1923, its canonical allegiance was officially transferred from the Moscow Patriarchate to the Ecumenical Patriarchate of Constantinople. These events were a response to the aspirations towards a national Orthodox Church that a group of Orthodox "nationalizers" had cultivated already at the turn of the $20^{\text {th }}$ century. Moreover, and even more significantly, these changes were planned and brought into action in cooperation with the representatives of the Finnish government. The aim was to create a national Finnish Orthodox Church and thus prevent any conflicts of interest with Church authorities beyond the eastern border, in other words, to uproot Finland's Orthodox minority from its Russian background.

In popular Finnish historiography, the process of nationalization has generally been considered a story of success. From this perspective, the Orthodox minority emerged from the tumultuous years of early in-

\footnotetext{
* Maria Takala-Roszczenko, Postdoctoral researcher, University of Eastern Finland, Address: Matarakatu 35,80130 Joensuu, Finland, e-mail: maria.takala@uef.fi

1 Mika Nokelainen, Vähemmistövaltiokirkon synty. Ortodoksisen kirkkokunnan ja valtion subteiden muotoutuminen Suomessa 1917-1922, Helsinki, Suomen kirkkohistoriallinen seura 2010, p. $130-158$.
} 
dependence as a religious community that had proven its loyalty to the government of Finland and was emphatically Finnish in its cultural orientation and identity. Yet, as any adaptation process, the "Finnicization" of the Orthodox Church was a far more complex development which involved considerable self-inspection and self-regulation, re-evaluation of the old and the customary, and some rather over-reaching attempts to testify the patriotic inclinations of Finnish Orthodoxy, including its liturgical expression.

This article analyses the state of Orthodox liturgy in Finland in the early decades of the $20^{\text {th }}$ century in light of nationalization. It focuses on public discourse about modifying the existing liturgical practices in the 1920-30s. Many of the issues raised during these decades had already been on the forum, yet now they resurfaced with an articulated emphasis on their national importance. The source material consists of articles published in the leading magazine of the Finnish Orthodox Church, Aamun Koitto ('The Dawn'), which was the forum for official announcements as well as for debate. The pervading question in this article is: how were these changes - factual or suggested - justified in the published discourse in terms of contributing to the nationalization of the Orthodox Church in Finland?

\section{Methods and sources}

Approaching liturgical adaptation not solely as a historical process but more from the perspective of how the changes were justified or argued by different writers, places this analysis in the framework of social constructivism in which the use of language is perceived as loaded with meanings and social reality as constructed through communication. Methodologically, the textual sources are thus approached as contributions to the "national" discourse in the Finnish Orthodox Church, which employ various rhetorical means in support of their arguments.

By focusing exclusively on the source material provided in the Aamun Koitto magazine, the scope of this article is obviously restricted to published texts that, prior to their publication, had been selected by the editorial board of the magazine. A great number of news and articles are anonymous, which suggests that they were written by editors themselves. The validity of these sources as reflections of public opinion can thus be rightfully questioned. Yet, as a magazine of the official missionary organization of the Church, the Brotherhood of SS Sergius and German of Valaam, Aamun Koitto most likely communicated views that were also accepted by the official representatives of the Church. Therefore, as the leading public medium of the Orthodox Church at the time, its role as a tool for influencing, if not manipulating, its 
audience was beyond comparison. This makes the national discourses conveyed by the magazine particularly interesting.

The underlying premise of the argumentation concerning nationalization in Aamun Koitto is that "Finnicizing" the Church was fundamentally beneficial for its existence. This argument was nothing new - from the very first issue of the magazine in 1896, its aim had been to strengthen Orthodox spirituality among the Finnish-speaking members of the Archbishopric of Finland whose hierarchy, down to the parish organization and liturgical life, functioned predominantly in Russian or Church Slavonic languages. However, after 1917, the emphasis shifted onto the status of the Orthodox in the independent Finland: nationalization came to be understood as a prerequisite for establishing a Church that justified its existence in the new Republic.

This was in many ways a psychological process which called for a new way of demarcating identity. The old heritage needed to be re-evaluated, even defamiliarized and discarded, new features adopted, in order to enhance functioning in a changed society. As such, it was comparable to a process of adaptation effected by moving into a new environment as a result of, for example, immigration. In social sciences, processes of this kind have been conceptualized as cross-cultural adaptation which ultimately aims at a certain degree of assimilation. ${ }^{2}$ The national discourse in the Finnish Orthodox Aamun Koitto is particularly interesting in this light, because through their arguments, it could be suggested, the authors not only sought to convince the audience about the benefits of nationalization, but also participated in a psychological process of adaptation which aimed at a successful negotiation of Orthodoxy with Finnishness on the level of identity.

\section{Negotiating Orthodoxy with Finnishness}

In 1919, the mitered Archpriest Sergei Okulov greeted the representative of the Finnish government, E.N. Setälä, at the Council of the Greek Catholic Church of Finland:

We assure that the population of our Church feels part of the Finnish nation and, as such, it wishes to develop and grow and, within its limits, give its contribution to the state and the national organization of Finland. ${ }^{3}$

\footnotetext{
2 Young Yun Kim, Becoming Intercultural - An Integrative Theorgy of Communication and Cross-Cultural Adaptation, Thousand Oaks - London - New Delhi, Sage Publications, Inc. 2001, p. 10.

3 S.n., "Suomen kreikkalais-katolisen kirkkokunnan ylimääräinen kirkolliskokous," in: $A a-$ mun Koitto 12\&13/1919, p. 111. (Translations from Finnish into English hereafter by the author.)
} 
Okulov's declaration of loyalty in the name of the Orthodox Finnish population reflects the situation in which the Church found itself after the geopolitical changes in the post-World War I Europe. In short, it conveyed the message that being Orthodox was no obstacle to being Finnish.

Fundamentally, the negotiation of Orthodoxy with Finnishness arose from the historical position of Finland between two realms, Sweden and Rus(sia), which had over the centuries extended their rule over the Finnish territory along with their respective spheres of Christianity - Roman Catholic and later, Lutheran, from the West and Orthodox from the East. Orthodoxy in Finland was thus characteristically of Russian origin.

The main challenge that Orthodoxy faced in Finland was the generally deep-rooted antipathy in society to issues related with Russia, which was the legacy of the Russian imperialistic rule of Finland between 1809-1917, and especially of the oppression of the Finnish national awakening around the turn of the century. When Finland seized its opportunity to seek independence from Russia, the anti-Russian sentiments were unleashed. This was particularly felt in the 1920s-30s when the political atmosphere in Finland was decidedly rightist.

When the Socialist Revolution cut the ties between the Russian Orthodox Church and the Archbishopric of Finland, the fate of the Finnish Orthodox depended on the goodwill of the new government. Financially, the Church was in severe crisis, because the Holy Synod had generally provided for the parishes in Finland. Politically, the Orthodox Church in Finland was burdened with its past position as a tool of Russification, which in the years of uncertainty surrounding the Civil War of Finland (1918) was a threat difficult to ignore. As it was in the interest of the Senate of Finland to strive for stability, the State assumed an active role in organizing the Orthodox Church and especially its canonical position. In 1921, the Church received autonomy from the Russian Church, and in two years, the Finnish Archbishopric received a Tomos from the Ecumenical Patriarchate as its autonomous daughter Church.

The foundation for the nationalization of the Church had already been laid in the $19^{\text {th }}$ century when the Holy Synod had allowed the use of the Finnish language in liturgical practice in parishes where the native tongue was spoken by the majority. In 1923, Finnish became obligatory also in parish documentation. The Finnicization of the Church in terms of language was a key factor for improving the status of the Orthodox in the Finnish-speaking society. Another factor was the adoption of the Gregorian calendar, for which the Patriarch of Moscow gave his consent in December 1917. Although this inevitably meant a breach with the rest of the Orthodox world, as it meant 
celebrating Easter together with the western Churches, the Finnish Orthodox Church now functioned in synchrony with Lutheran Finland at least during the main Christian feasts. Yet Orthodoxy continued to be viewed very much as "the Other" in Finnish society. This created an underlying pressure that ignited the nationalization of the Orthodox Church of Finland.

\section{The Nationalization of Liturgical Tradition}

\section{Criticism of Ceremonialism}

One of the essential questions discussed in the context of nationalization was the mystical character of the Orthodox liturgy. From a critical point of view, the divine services of the Eastern Rite appeared as burdened with outward ritualism and outdated ceremonies. Ceremonialism, it was argued, would grow at the expense of true faith, and the outward customs would make the spirit wither. ${ }^{4}$ As a critical observer noted in 1918,

[i]f the Church still remains spiritually so empty as it so far has been. If there will be only an endless amount of those Old Testament ceremonies, a great number of mechanically read and many times repeated prayer-readings, gospels and epistles made unclear by the half-chanting manner of reading, unbiblical doctrines on saints, Virgin Mary, etc., and if it believes and makes others believe in the prayers for the living as well as for the dead, conducted there for money, then this Church is no longer up to date, and as such it has no future in this Finland that is now being built here on the principles of freedom. ${ }^{5}$

The concluding argument makes an interesting contrast between the Finland of the future that is being "built on the principles of freedom" and, supposedly, the Finland of the past, lacking that freedom, whose epitome is the obsolete, even corrupted (as the reference to paying for the prayers implies) Church. The Church needs to rid itself of "spiritually empty" ceremonies in order to be compatible with the new social order. The argumentation is in line with the popular association of Orthodoxy with the Russian "Orient", and this seems to be the angle from which the traditional liturgy is criticized, for the author continues:

Yet if it [the Church] awakens and sees that it has been left far behind its evangelical Christianity, which is based on the Bible,

\footnotetext{
4 Mikael Michailov, "Kirkastakaa Jumalaa ruumiissanne ja hengessänne, jotka ovat Jumalan," in: Aamun Koitto 24/1918, p. 191.

5 A.N. O:v, “Onko kreik.-katol.kirkolla Suomessa olemassa mitään tulevaisuutta?” in: $A a-$ mun Koitto 14/1918, p. 113.
} 
[...] [a]nd if it then [...] takes a decisive step towards a thorough reformation, placing its cornerstone in Jesus Christ alone and nothing else, and, so to say, nationalizes, removing from itself all with which it has become tangled in the course of times as oriental elements, foreign to the Finnish nation [...], it is then and only then that it has its future and its great Christian mission also here in Finland. ${ }^{6}$

The ceremonies of the Church are evaluated as "oriental" that are inherently "foreign" to Finns, something with which the Church has (perhaps even involuntarily) become tangled with, and accordingly, can be discarded. The argumentation relies on numerous references to the Bible (particularly the New Testament) as the sole authority in the Church, as opposed to Tradition. The cult of the saints, and of Virgin Mary, are suspicious because they appear as "unbiblical" - it should be Jesus Christ alone, on whom the Church bases its existence. Ceremonies and rituals are regarded as remnants of the Old Testament, also judged as obsolete at the dawn of the brave new national order.

It is clear that this critical account arises from a society in which a Protestant ethos dominated, from the Bible-centred teaching of the Lutheran Church, and possibly the austere puritanism of various sects that were gaining space in Eastern Finland in the early decades of the $20^{\text {th }}$ century. The bias is clear to the author of the text:

I am almost certain that there are people who, having read my writing, tend to say I would like to Lutheranize the entire Greek-Catholic Church. I answer to them - I do not wish so. But I would dearly wish that this Church would become biblical and the Church of the New Testament. ${ }^{7}$

The Lutheran influence aside, the account is a testimony to the fact that the symbolically loaded liturgy of the Orthodox Church had failed to make sense to some of its own members. For centuries, the divine services had been literally incomprehensible to the Finnish-speaking population due to the use of Church Slavonic. There are several testimonies to the fact that in many Karelian parishes, public demonstrations of faith - prostrations, sign of the Cross, fasting, venerating icons - had become rare among common people. Where Orthodox customs were observed in daily practice, they had often become infused with superstition. These challenges were addressed in several articles in Aamun Koitto, as different writers evaluated the state of liturgy in an answer to arguments such as discussed above. "Mysticism"

6 Ibidem, p. 113.

7 Ibidem, p. 113-114. 
in the sense of traditional liturgical ceremonies was described as worth preserving, because it uplifted the human soul as an element of beauty. ${ }^{8}$ Daily observance of Orthodox customs was also deemed as necessary, because "outward signs" supported people in their faith in a practical way. ${ }^{9}$ Yet there seems to have been one point commonly agreed on: the contemporary state of liturgy called for a reformation of certain degree in order to make it more attractive to believers.

\section{Reforming the Liturgy}

In the early decades of its autonomy, the Finnish Orthodox Church struggled with establishing a liturgical tradition of its own, with two aspects to consider: the unification of the divine services especially with respect to making reductions in them, and the manner of celebrating them. For many parishes, it was also a period of transition from the Church Slavonic liturgical services to the Finnish translations which were still scarce in number. Nationalization served as the context for many ideas of reform in the liturgy, although it was recognized as a very delicate matter especially by the clergy. "If the nationalization of the liturgy here in Finland," noted Archpriest Sergei Okulov in 1918,

will require changes in the ritual, then the need has to be satisfied, but satisfied very cautiously, so that it would cause no dismay to any of our brothers, and satisfied only when our Church expresses its will at its general synods fully comprehensibly and with a great majority of voices. ${ }^{10}$

The need for uniformity in the divine services was recurrently discussed at the brotherhood meetings of the Finnish clergy, as well as in the Aamun Koitto magazine. New ideas were often accompanied by justifying arguments about the natural evolution of liturgy, for example,

[w] know from the history of the Church that clinging blindly to old customs has created an obstacle to inner development. And the real liturgical life has always been under development. ${ }^{11}$

However, there were different perspectives to the extent and aims of "developing" liturgy. At the clergy's meeting in 1934, priest Lauri Mitronen presented a rather ambiguous account on the state of things:

\footnotetext{
8 P.T., "Mystillisyys jumalanpalveluksessamme," in: Aamun Koitto 4/1918, p. 28.

9 M. Michailov, "Kirkkomme olemus," in: Aamun Koitto 16/1918, p. 126.

10 Sergei Okulov, "Onko kreik.katol. kirkolla Suomessa olemassa mitään tulevaisuutta?” in: Aamun Koitto 14/1918, p. 111.

11 S.n., Valamon luostarissa pidetyn Suomen kreikkalaiskatolisen kirkkokunnan papiston veljeskokouksen pöytäkirja 1934, p. 24.
} 
We have inherited from our Mother Church the liturgy, which in the course of a long and sometimes monotonous development has been enriched mostly in its external aspects. Many external Offices and different parts of the divine services which have had no special significance, other than as historical remnants, have remained unchanged up to our days. Yet now part of them begins to be left out from practice, and in the place of some, new and more impressive parts are being formed. The religious life of our nation shall bring forward new needs for liturgical offices and create more liturgical forms and external customs that comply with national life. ${ }^{12}$

The argumentation is firmly rooted in the national discourse, in which it is the nation, not the Church, that creates the criteria for liturgy and evaluates and extracts the parts that are useable while discarding those that have become obsolete. Yet the speaker did not elaborate on the means through which these ideas were to be realized but concluded by emphasizing the significance of preserving uniformity in liturgy. Moreover, the priests should aim at reflecting the solemn greatness and the inner beauty of the divine office in their conduct, he underlined. ${ }^{13}$

These aspects had been widely discussed already between 1926-27 by Rev. M. Michailov, the Dean of the North Karelian parish of Taipale, who delved into questions of the liturgy in his articles in Aamun Koitto. Michailov stressed that it was natural for each local Church to organize its external life so that it suited the "contemporary circumstances and other sources of influence"; ${ }^{14}$ yet he called for

improving our divine services, - not by creating or making new, which we cannot, but by organising the existing ones and by celebrating them in such a way that the souls of those who are lost to this world would find God, peace and rest in them. Let us begin this before we are left all alone in our churches! ${ }^{15}$

Perhaps from his own experience in rural parishes, Michailov saw the potential outcome of people's disenchantment with the excessive ceremonialism in Church, as well as of the lack of uniformity in its liturgy. "In some churches," he explains,

by the order of the superior, they read everything that is written, not caring at all if it is useful or not. In other churches they reduce

\footnotetext{
12 Ibidem, p. 24.

13 Ibidem, p. 24.

14 M. Michailov, "Jumalanpalveluksista," in: Aamun Koitto 21/1926, p. 203.

15 Idem, "Jumalanpalveluksista," in: Aamun Koitto 1 / 1927, p. 3.
} 
the reading when the superior understands that it is the letter that mortifies and the spirit that makes alive. Life has fully shown that it is impossible to celebrate the services in parish churches according to the Typika. The Church of Constantinople has noticed this for ages ago and they have a different Typikon for lay parishes. And such manual for the divine services, such new Typikon our Church badly needs for the lay parishes, if we wish to reach relative uniformity in the liturgy and if we do not wish to extinguish the people's wish to come to the house of the Lord with long, stagnated services. ${ }^{16}$

It was thus a sign of good leadership and understanding that a priest made reductions to the divine services. For concrete actions, Michailov suggested, for example, that the all-night vigil be stripped of tautology:

Since the Great Litany is pronounced at the beginning of the service, it does not have to be repeated after the Hexapsalmos, but could be replaced with a Small Litany. The reading of the Hexapsalmos could consist of three psalms on one Sunday and other three on another. The Small Litanies before the Gospel and within the Canon should be left out. "Blessed Is the Man" and the Kathismata could be chanted and recited only on great feasts. ${ }^{17}$

Michailov also addressed the reading of the so-called secret prayers during the Divine Liturgy. In his view, the congregation ought to be able to see what takes place in the altar and to hear the prayers in full. "This is possible if during the Divine Liturgy the Royal Doors are kept open for the whole time and closed only for the moment when the clergy participates in the Holy Communion," he argued. ${ }^{18}$ His suggestions echoed the petition issued by a group of Finnish Orthodox clergy already in $1906,{ }^{19}$ and indeed, they were in line with ideas of liturgical renewal discussed in the Russian Orthodox Church in the early $20^{\text {th }}$ century.

Michailov's concerns were thus of pastoral nature; his aim was not to nationalize liturgy as such but to enliven it, to make it more approachable and comprehensible for the congregation. Yet the goals set for reforming the liturgical services for the sake of active lay participation and for the sake of nationalization seem to have coincided in many ways. The reduction of

16 Idem, "Jumalanpalveluksista," in: Aamun Koitto 21/1926, p. 203-204.

17 Idem, ”Jumalanpalveluksista" in: Aamun Koitto 2/1927, p. 16.

18 Ibidem, p. 16.

19 S.n., "Minkälaisiin toimenpiteisiin olisi hiippakuntamme kirkollisten olojen parantamiseksi ryhdyttävä?" in: Aamun Koitto 4/1906, p. 53. 
tautology, the removal of obsolete ceremonies, the certain demystification of the divine services by revealing them for the eyes and the ears of the laity in a comprehensible language - all these points served equally the purposes of nationalizing the liturgy.

\section{The Committee for Nationalizing the External Forms of the Orthodox Church}

The most significant organ for nationalizing Orthodoxy in Finland was the Committee for Nationalizing the External Forms, founded by the second Council of the Church of Finland in 1925 and active until 1935. The Committee's plans revealed patriotic intentions at their extreme, which is probably the reason few of its aims were realized. Yet even the discussion around the Committee's functions reveals how far certain nationalizers were ready to go in Finnicizing the Church.

The Committee was founded at the initiative of Iivo Härkönen, a writer and an activist in many fields of Karelian culture, and its nationalizing efforts concentrated on "external forms" of Orthodoxy, i.e., architecture, iconography, and liturgical vestments. Härkönen, who was also a lay representative at the Church Council, explained the urgency of the matter:

It is extremely important for the life, development and preservation of the Finnish Greek Catholic Church in contemporary circumstances that it, if possible, and the sooner the better, disengages from such foreign external forms that are not indispensable to its inner nature, and in an equal measure unites with national forms that only bring it closer to the nation and its soul. ${ }^{20}$

This emphasis on the external aspects of religious life, recurrently encountered in the national discourse, is highly interesting. At the stake was the visible side of the Church, the public image of Orthodoxy in Finland, potentially (and in truth, often quite openly) criticized by some Lutheran Finns. Thus, by seeking to efface the foreign forms and to replace them with "national", the activists engaged in a psychological process of cultivating the image and the identity of the Finnish Orthodox. The changes, justified by Härkönen as imperative for the preservation of the Church in the State of Finland, would evidence to the outsiders that the Orthodox Church was no longer a representative of the foreign rule, but patriotic and inherently Finnish. At the same time, the nationalization of art and architecture would make the Church more appealing to the Finnish Orthodox population, because they would automatically recognize the new forms and ways of expression as their own.

20 S.n., "Kirkkokuntamme toinen lakimääräinen kirkolliskokous," in: Aamun Koitto 16/1925, p. 148. 
This powerful rhetoric was heartily embraced by the Church Council because "these observations and thoughts [were] not likely to be foreign to any truly Finnish Greek Catholic", as it was noted. ${ }^{21}$ In more detail, it was agreed that in the renovation of churches and the building of new ones, "purely Finnish forms of [...] art" would be used, and that all items with writing (including inscriptions on icons) should immediately be changed into Finnish language, and that liturgical vestments should become more modest in style and draw on "Finnish shapes." 22 To coordinate the nationalizing efforts, a Committee was founded with Bishop Herman, Archpriest S. Solntsev, Rev. M. Michailov and the initiator, Iivo Härkönen, as its members.

In early 1926, some concrete plans of the Committee (drafted by Iivo Härkönen) were evaluated and mainly accepted by the Synodal Office. The technique of nationalization was very much based on de-familiarization of objects and symbols that had until then been accepted as Orthodox tradition. Symbols such as the crescent or the tilting crossbar in the Slavonic type of a cross would be removed from church items. ${ }^{23}$ For the daily outfit of the clergy, a Lutheran type of straight, black jacket with a hard white collar was preferred. The draping in liturgical vestments would be softer, looser, and their colour would be restricted to silver, gold, and the Finnish national colours (the colours present in the flag of Finland), blue and white. ${ }^{24}$ The church interior would be accommodated in order to "remove the mysticism that often has been associated with the altar", in other words, the iconostasis was to be as transparent as possible. The choir, which in contemporary practice attracted too much attention of the congregation at their place on the kliros, was to be placed in a choir loft at the western end of the church. A place for delivering sermons, possibly a pulpit, was to be built on the lefthand side of the kliros. ${ }^{25}$ The most culturally and politically loaded form of church architecture, the onion-shaped dome, was to be replaced with a straight church tower which a later critic of Härkönen sarcastically called "a carrot shape"26.

The resemblance between these new national forms and the church architecture and items, not to mention the clergy's clothing, of the Lutheran

\footnotetext{
21 Ibidem.

22 Ibidem.

23 S.n., "Suomen kreikkalaiskatolisen kirkon muotojen kansallistuttaminen," in: Aamun Koitto 4/1926, p. 33.

24 S.n., "Suomen kreikkalaiskatolisen," p. 33.

25 Ibidem.

26 Mikael Fiilin, "Sanakiista siirtyy toisille aloille," in: Aamun Koitto 20/1930, p. 162.
} 
Church in Finland, was obvious. Many members of the Orthodox Church undoubtedly viewed the external assimilation to the culturally very Lutheran society as a positive thing, because, once realized, it would diminish opportunities for discrimination on the grounds of appearance.

While the work of the Committee for Nationalizing the External Forms was restricted to physical objects, it provided an ideological context for ideas that concerned "internal" forms, as well. This can clearly be noted in the articles concerning church music that were particularly numerous in the Aamun Koitto magazine in the 1920s-30s.

\section{Liturgical Performance and the National Ideals}

The initiator of the discussion about liturgical performance, mainly church music but also liturgical reading, was - rather unsurprisingly - the main activist of the Nationalizing Committee, Iivo Härkönen. His first writing on questions of liturgical singing, particularly of chanting in the Finnish language, was published as early as in $1898,{ }^{27}$ yet his main contribution consisted of poetic re-translations of liturgical hymns that were published in Aamun Koitto from 1922 onward. These translations were patriotically inspired, and they were aimed at congregational singing. In an article titled "The Reform of Church Music in the Greek Catholic Church of Finland", Härkönen argued for the establishment of congregational singing in the Finnish churches.

Special choral chanting, of which the church music in the Greek Catholic Church has, up to now, consisted everywhere almost entirely, is by no means to be removed, at least in its entirety, rather it should be in proper measures promoted and developed, but it is not the kind of singing in which the congregation can participate. It is left to a certain few, specially trained people [...]. For this reason, along with this artistic and more complicated chanting, a simpler, easier way of congregational singing must be initiated and developed. In western churches, there has been from early ages on an effort to create church hymns into more regulated, rhymed texts, which naturally require the melodies to be formed accordingly. (...) Thus, and since there is not likely to be any impediment found in the Bible to creating and practicing such music, it has been thought, that the reformation of church music in the Finnish Greek Catholic Church, if it wishes to reach its full meaning, must proceed in this direction. ${ }^{28}$

27 I-o H., "Sananen kirkkolaulustamme," in: Aamun Koitto 2/1898, p. 19.

28 Iivo Härkönen, "Suomen kreikkalaiskatolisen kirkon kirkkolaulun uudistus," in: Aamun Koitto 22/1922, p. 177-178. 
Härkönen thus argues for the transformation of the musical performance in the church. The tradition of professional chanters who were associated with the clergy (and who had mainly clerical training) is to allow the growth of congregational singing which would eventually prove the most beneficial style of chanting. Particularly interesting is the reference to the Bible as the authority against which this innovation is to be checked; something that resembles the accounts discussed earlier in this article.

Yet, in fact, in this question Härkönen participated in an already well-established discourse that had characterized Orthodox religious magazines in Russia and Ukraine in the late $19^{\text {th }}$ and early $20^{\text {th }}$ century. ${ }^{29}$ In these articles, congregational singing had been viewed as quintessential to the spiritual growth of the church-going masses. The discourse reflected the aspirations for liturgical renewal in Russia, in which the assembly of the faithful, the sobornost' of the church community, was at the core. ${ }^{30}$ It is possible that Härkönen's initiative was influenced by Russian views, and it is certainly plausible that he found inspiration in western (Lutheran) congregational singing, as this is what he mentions in the cited passage. Yet the main spark for these ideas came from Estonia which was considerably ahead of Finns in the nationalization of the Orthodox Church.

Already in 1919, livo Härkönen (using the pseudonym “-o") related some aspects of Estonian Orthodoxy in Aamun Koitto.

The chanting in the Estonian language echoes beautifully in Estonian churches, it upliftingly influences the sense of nationality; there are Estonian inscriptions from the Bible at the doors of the churches, within the walls of the church, and explanations in the same language, written on the holy images, give the house of the Lord a homely, national atmosphere. When can we get this far in Finland?31

The chanting in Estonian churches was based on stanzaic, rhyming hymns with religious content, and it was these hymns with which the churches echoed. ${ }^{32}$ Härkönen was likely to use these riimilaulud (Estonian

29 Nataliya Kostyuk, "Congregational Singing in Divine Services," in: Church Music and Icons: Windows to Heaven. Proceedings of the Fifth International Conference on Orthodox Church Music, University of Eastern Finland, Joensuu, Finland, 3-9 June 2013, Joensuu, The International Society for Orthodox Church Music 2015, p. 334-344.

30 Hyacinthe Destivelle, O.P., The Moscow Council (1917-1918). The Creation of the Conciliar Institutions of the Russian Orthodox Church, Notre Dame, Indiana, University of Notre Dame Press 2015, p. 18-19.

31 -o., "Hiukan Viron kirkollisista pyrkimyksistä," in: Aamun Koitto 21/1919, p. 178.

32 Jeffers Engelhardt, Singing the Right Way: Orthodox Christians and Secular Enchantment in Estonia, Oxford, Oxford University Press 2015. 
for "rhyming songs") for a model when he compiled poetic renditions of liturgical hymns and psalms for the Divine Liturgy and the All-night Vigil. The author took many liberties to vivify the ancient texts, as can be seen, for example, in his poem based on the Cherubic Hymn. ${ }^{33}$ These poems, intended to fill the Finnish churches with congregational singing, failed to take root in liturgical practice because they existed mainly only as texts, waiting to be composed in music. ${ }^{34}$

The ideal of congregational singing was nevertheless adopted in the Finnish Church with a notable emphasis on its national character. It was to serve against the movement of people away from Orthodoxy to Lutheranism or various sects, because as people wished to sing at services and had no opportunity to do so at their own church, the temptation of the Lutheran hymns with their easily memorized melodies and rhyming stanzas proved significant. The nationalizers, Archbishop Herman on the front line, called for more congregational singing in the parishes, and worked tirelessly for providing training, material, and motivation for cantors and teachers.

The use of instruments created a problem that was widely discussed in the 1920s-30s. Instrumental accompaniment to hymnody, mainly the organ, was used in the Lutheran services. Discussing the ways of improving choral or congregational singing in the Aamun Koitto magazine, the Orthodox writers frequently, though tentatively, mentioned the possibility of adopting the organ in the divine services, or at least at rehearsals. Especially in parishes where the Orthodox families were scattered around a wide area and where regular rehearsals were difficult to organize, the use of an instrument was suggested as a way of replacing the choir.

We, Greek Catholics, are usually afraid of such novelties, we think of them as imitating Lutheranism. But if the novelty can be beneficial for Greek Catholicism itself, in my opinion, it is not to be

33 The Byzantine offertorium hymn from the 6th century has the following content: "We who in a mystery represent the Cherubim and sing the thrice-holy hymn to the life-giving Trinity, let us now lay aside every care of this life [...]." In Härkönen's interpretation, it verges on pathetic and comic: "Now we in secrecy, silently / represent the high / fluttering of the angels / Cherubim, Seraphim - / bow down, behold! - / the opening of the heavens, / the coming of the gifts holy - / see, receive!” Translation from Maria Takala-Roszczenko, " "Imported on a jet-plane»: the Byzantine «revival» in Finnish Orthodox church music in the 1950s-60s," in: Church Music and Icons: Windows to Heaven, 3-9 June 2013, Joensuu: The International Society for Orthodox Church Music 2015, p. 303-311.

34 A few of the poems were set to music. The most notable of these was the already mentioned Cherubic Hymn which was composed by a Finnish musicologist, Ilmari Krohn, and was reported as a hymn "chanted instead of the communion verse" at a Divine Liturgy in Kitelä. S.n., "Sisälähetysjuhla Kitelässä ja p. Sergein ja Hermanin Veljeskunnan vuosikokous," in: Aamun Koitto 16/1925, p. 147. 
dreaded. Why could we not organize congregational singing at church with the help of an organ, if the use of an organ would be just an innovation in church customs and not contradict the doctrine of the Church in any way. ${ }^{35}$

The argumentation concerning the use of instruments resembles the way in which ceremonies and religious customs were also evaluated. The writers justified the change from strictly vocal chant tradition to accompanied music by claiming the irrelevance of the change, as it did not concern doctrinal questions. ${ }^{36}$ Iivo Härkönen pointed to the Bible as the authority in this question, as well: since King David encouraged the praise of the Lord with instruments in his psalms, "perhaps a suitable instrument could be taken into practice, at least at the religious meetings and house prayers." ${ }^{37}$ Archbishop Herman was a supporter of the use of instruments, probably because of his Estonian background; he reflected on chanting with the accompaniment of instruments, even a brass orchestra, in a positive tone. ${ }^{38}$

Yet there were no official statements encouraging or discouraging the use of an organ in worship. The lack of instructions puzzled the chanters, and it was considered a question too important for them to decide. ${ }^{39}$ At a brotherhood meeting of the Finnish clergy in 1932, the participants concluded that there was no need for an instrument in the divine services. ${ }^{40}$ Where available, however, the instrument was used at choir rehearsals, and parishes were encouraged to invest in an organ to raise the level of chanting. Reports on various prayer meetings, organized not in a church space but in school buildings and such, mention that liturgical hymns were frequently sung with an organ accompaniment. For example, two Orthodox seminarians conducted missionary events in the parish of Suojärvi in 1926. At a prayer meeting in Kaitajärvi, the programme included "an introductory speech, O Heavenly King, the 3rd Hour, the Gospel, a sermon based on Ro-

\footnotetext{
35 Diakoni, "Yhteislaulusta jumalanpalveluksessa," in: Aamun Koitto 6/1920, p. 47.

36 In truth, there were no prohibitions issued against the use of instruments in the Orthodox Church. The Church Canons are silent in this respect, but as Hilkka Seppälä argues, the silence indicated the unanimous acceptance of non-instrumental music in worship. Canonical regulations were, after all, mostly reactions to a problem or challenge which called for the official opinion of the Church. See Hilkka Seppälä, "Kirkkolaulua koskevista kirkollisista säännöistä,” Sanasta säveleen 2, Joensuu: Joensuun yliopisto 2006, p. 71.

37 Iivo Härkönen, "Suomen kreikkalaiskatolisen kirkon kirkkolaulun uudistus," in: Aamun Koitto 22/1922, p. 178.

38 Piispa Herman, "Kirkkolaulu Virossa," in: Aamun Koitto 23-24/1925, p. 226.

39 X., "Laulunharrastajain kokous Valamossa," in: Aamun Koitto 13-14/1929, p. 148.

40 S.n., "Papiston veljeskokous," in: Aamun Koitto 25/1932, p. 200.
} 
mans 10:10, O Gladsome Light (accompanied with an organ), Praise Ye the Name of the Lord (with organ accompaniment), prayers, a speech, and It Is Truly Meet." ${ }^{1}$

There seems to have been, however, a clear idea of the distinction between playing the organ at lay meetings as opposed to liturgical services celebrated at church. An obvious reason for this was, naturally, the fact that organs were not part of the Orthodox church interior, whereas it was rather a standard equipment at schools. An interesting case was reported from the parish of Suistamo where the cantor Sergei Mihailov had played all the hymns of the Divine Liturgy with an organ. The Synodal Office reproached Mihailov for this, stating that such was not allowed. However, the particular service had taken place in a village school building. ${ }^{42}$ The cantor in question seems to have been tempted by the availability of an instrument as the Liturgy was not celebrated in a church.

The connection between reforming church music and nationalizing the liturgy was not discussed in a very explicit way in the Aamun Koitto magazine, although the national ideals were in full accordance with promoting congregational singing and adopting elements from the Lutheran liturgical practice. Instead, the discussion that focused on liturgical reading based its rhetoric on deeply national arguments. It was ignited in 1930 by a report on a Divine Liturgy in which the celebrant himself, Mikael Fiilin, evaluated the aesthetic outcome of the service and praised especially the "artistic" reading of the hours and the epistle. This evaluation began a fiery debate between a

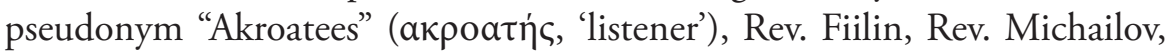
and Iivo Härkönen. In essence, it was a clash between nationalizers and those who appreciated the traditional Slavonic performance style in liturgy.

Akroatees criticized the "singing" style of reading the epistle, which, according to his description, began in an "unnaturally low and hollow voice due to the incorrect use of the diaphragm", rose sentence by sentence higher and higher, ending up in an "unclean falsetto that broke unexpectedly due to the non-existent breathing technique". It was the style that reading in Church Slavonic necessitated, the writer argued relying on "specialists of Church Slavonic", but such a horrendous style could never be applied to the Finnish language whose correct reading required a calm expression and the clear pronunciation of the syllables. "Our dear Finnish language is vocal music, by which feature it is widely known as at least the third most

${ }^{41}$ S.n., "Puolitoista viikkoa Suojärven kreikkalais-katolisten keskuudessa," in: Aamun Koitto 12/1926, p. 110.

42 Archive of the Synodal Office, Kuopio, Finland. Letters 1934, F 508. 
beautiful language in the world," argued Akroatees, repeating, "the Finnish language, even when read, correctly, is music." ${ }^{43}$ Thus the initially innocent description of liturgical performance was transformed into a language political argument, through which the Church Slavonic language was associated with a "horrendous" old style of reading, against which the national Finnish was - quite amusingly - classified as the quintessence of beauty and music that did not need such "unnatural" techniques of performance.

Participating in the debate, Rev. Michailov, one of the members of the Nationalizing Committee, saw no reason why Finnish could not be used for this type of reading, but from his own perspective the "singing manner" hindered the understanding of the text and made the services considerably too lengthy. ${ }^{44}$ Already in 1927, Michailov had estimated that if the clergy officiates by means of "speaking, not singing", the maximum length of regular Sunday Matins is one hour. ${ }^{45}$ Quite interestingly, he seems to imply that the liturgy was not recited, as in the Slavonic Orthodox tradition, but read in a plain voice as, for example, in the Lutheran church. Whether this was indeed a commonly practised style of performance, the Aamun Koitto magazine does not provide enough clues. In any case, the casual manner of Michailov's comment implies that this deviation from tradition was not considered an anomaly of any sort.

Iivo Härkönen, who was drawn into the debate as Rev. Fiilin's suspect for the pseudonym "Akroatees", commented on the question of liturgical reading quite moderately, in agreement with Michailov in that the recitative style could be used in the Finnish language if it was done with a good aesthetic taste. Yet he was provoked by Fiilin's accusations and used the forum for arguing his nationalizing views in an unexpectedly coloured way. Once more, by association with the Russian tradition, the familiar shapes and physical items together with the technique of reciting were de-familiarized and pictured as "oriental" and "thoroughly foreign" to Finnish Orthodoxy:

I have fully openly stated my thoughts, behind which I stand and behind which I know many other Finns and Karelians to stand. The Russian onion-towers and foreign oriental robes, well, against those, Mr Fiilin, we shall always stand.

\footnotetext{
43 Akroatees, “Taiteellisesta rukouksien laulamisesta," in: Aamun Koitto 13/1930, p. 103104.

44 M. Michailov, “Taiteellisesta rukouksien lukemisesta," in: Aamun Koitto 15/1930, p. 117.

45 M. Michailov, “Jumalanpalveluksista," in: Aamun Koitto 2/1927, p. 16.
} 
[...] the useless roaring (the truly Russian, as-if-artistic gradual raising of the voice) is to be no more in our books and in the field of our Finnish language, as are the other sickeningly sweet and thoroughly foreign features to be entirely discarded in its [i.e. the church] forms, whether they be domes, onions, or even the beloved "riasas" [priest's robes]. ${ }^{46}$

The debate on the performance of liturgical reading was, in essence, more than an argument about ceremonies or church towers or pieces of clothing. By allowing the discussion to take place on its pages, the Aamun Koitto magazine revealed that the nationalizing campaign was far from unanimously accepted but that the officially promoted aims were regarded with passionate opposition by the likes of Rev. Fiilin. The participation of Iivo Härkönen also revealed that he was somewhat oversensitive about other people's attitudes toward his ideas of nationalization. His indignation, as Fiilin argued, implied that Härkönen was really rather alone in his radically patriotic views. "This detail only strengthens my unwavering state of mind and I speak clearly that there are also others who support my stance on the flagrant reforms," Fiilin concluded. ${ }^{47}$

During the period of most intense national discourse, different ideas fluctuated from one extreme to another. Although the Aamun Koitto magazine introduced, or only suggested, many innovations to the public, it is difficult to estimate whether the nationalizing efforts had a wide support among the Orthodox population. In the debate on liturgical reading, Rev. Fiilin noted that many of the reforms suggested by the Synodal Office were discussed behind closed doors and without the acceptance of the Greek Catholic population. ${ }^{48}$ Perhaps in a reaction to the leading role of laymen such as Iivo Härkönen in the nationalizing campaign, the brotherhood meeting of the Finnish clergy issued a petition in 1934 to the Church Council that it would not make decisions of issues relating to religion, canonical rules, divine services, liturgical books, church discipline, congregational work and the clergy's rights and responsibilities before the clergy had presented their own view on the questions. ${ }^{49}$

In the 1930s, more voices of moderation began to be heard. In an editorial note to Iivo Härkönen's flaring argumentation in the above dis-

46 Iivo Härkönen, "Huvittava sanakiista," in: Aamun Koitto 18/1930, p. 142.

47 M. Fiilin, "Sanakiista siirtyy toisille aloille," in: Aamun Koitto 20/1930, p. 162.

48 Ibidem.

49 S.n., "Papiston veljeskokous," in: Aamun Koitto 28-29/1934, p. 169. 
cussed topic, Archpriest Sergei Okulov sought to put the discussion into an objective perspective:

It is good to liberate oneself from the blind imitation of all things Russian and oriental, but it is not good to exchange it for the blind imitation of everything Finnish and western. Let our Church become free from both extremes and let it try creating its own independent forms, preserving from its churchly past what is valuable and good in it, and through careful measuring adopt new forms that the national spirit requires! ${ }^{50}$

A similar wish was expressed at the Church Council of 1930. It was hoped that in their decisions, the Nationalizing Committee would "select the best forms which were, above all, in harmony with the spirit of the Orthodox Church, even if it would mean the preservation of the old." 51 The idea of preserving the old tradition as an act of concession can indeed be seen as characteristic of the values and ideals of the nationalizing period in the Finnish Orthodox Church.

\section{Conclusion}

The nationalization of the Finnish Orthodox Church in the 1920s-30s was a process launched by the establishment of the Church in the independent Republic of Finland. It was to a large extent a reaction to the changed social and (church) political context, as the Orthodox Church was transformed from the church of the Russian authorities into a national minority church. The Finnicization, in essence, aimed at justifying the Orthodox population's right to exist on equal terms with other Finnish citizens in the national state. By striving towards reformed worship, congregational singing, "national" forms in church art and liturgical items, the Orthodox thus aimed at certain assimilation with the surrounding society in order to better function in it. Psychologically, it was imperative for them to negotiate their heritage with the new standards of society, to evaluate the essential in their culture and discard what was deemed as irrelevant. The national discourse in the Aamun Koitto magazine reflects this process which was by no means simple or uniform.

\footnotetext{
50 Sergei Okulov, “Toimituksen huomautus," in: Aamun Koitto 18/1930, p. 143.

51 S.n., Suomen kreikkalaiskatolinen kirkkokunta vuosina 1930-1933. Sortavala: Sortavalan kirjapaino Oy 1935, p. 7.
} 